DOI: https://doi.org/10.24297/jssr.v15i.8729

\title{
Too little or too Much Freedom? - A Comparative Analysis of Corporate Governance Codes in the UK and Australia
}

\author{
Badar M Almeajel Alanazi
}

Law Department, College of Science and Humanities Studies, Shaqra University, Saudi Arabia

balmeajel@su.edu.sa

\begin{abstract}
The purpose of corporate governance codes is to ensure that directors do not abuse their power to the disadvantage of the company's shareholders or creditors, while at the same time affording them enough freedom to allow the company to operate in a competitive way and generate profits. This article evaluates the UK Corporate Governance Code and the Australian Corporate Governance Principles and Recommendations in order to ascertain the extent to which they strike an appropriate balance between preventing abuses of power by the board while affording them sufficient freedom to pursue innovation and entrepreneurship. The article concludes that the codes in both countries propose advanced approaches to corporate governance which to a significant extent protect the interests of the shareholders while encouraging board members to pursue innovation and entrepreneurship in a safe manner, through the adoption of appropriate risk management measures.
\end{abstract}

Keywords: corporate governance, code of conduct, United Kingdom, Australia.

\section{Introduction}

The term 'corporate governance' refers to the system of processes and mechanisms available in a particular country to regulate the directing and management of companies (Bebchuk, Cohen and Ferrell, 2009). Corporate governance codes ("CGCs") tend to regulate the operation of the boards of directors in companies, typically by providing a set of principles which should be followed by the boards (Licht, Goldschmidt and Schwartz, 2005). The purpose of such codes is to ensure that directors do not abuse their power to the disadvantage of the company's shareholders or creditors, while at the same time affording them enough freedom to allow the company to operate in a competitive way and generate profits (Ramirez, 2007).

An overly restrictive approach imposed by a CGC could prevent companies from innovating by significantly slowing down the decision-making processes, which would in turn discourage companies from following the principles, particularly given their weak legal force (as will be discussed later in this article) (Bebchuk, Cohen and Ferrell, 2009). On the other hand, an excessively relaxed set of principles could lead to abuses of power by the board, which would be to the disadvantage of the company and its investors (Bebchuk, Cohen and Ferrell, 2009).

Therefore, a careful balance between the two approaches is required in order to achieve the purposes of corporate governance. The UK and Australia have both been considered as countries with highly advanced principles-based corporate governance codes (Du Plessis et al., 2018). As such, the UK Corporate Governance Code (Financial Reporting Council, 2018) and the Australia's Corporate Governance Principles and Recommendations (ASX Corporate Governance Council, 2019) will both be evaluated in this article as to the extent to which they strike an appropriate balance between preventing abuses of power by the boards of directors while affording those boards sufficient freedom to pursue innovation and entrepreneurship. In particular, the first section of the article will discuss the rationale behind the CGCs in the UK and Australia, while the following sections will examine each of the codes in light of the above criteria. Subsequently, a comparison of the two codes will be presented, followed by a set of recommendations based on the best practices identified in each of the codes. 


\section{Rationale Behind Corporate Governance Codes}

The publication of corporate governance codes cannot be said to have a long-standing tradition in either the UK or Australia. The first CGC in the UK was published in 1992 by the Cadbury Committee (The Committee on the Financial Aspects of Corporate Governance, 1992), whereas the first governance code in Australia was made available only in 2003 (Fleming, 2003). Since its introduction the UK Code established the principle of 'comply or explain', which required that companies should either comply with the principles set out in the Code or provide a rationale for their lack of compliance (Financial Reporting Council, 2018). This afforded the companies a certain degree of flexibility in following the Code's principles, provided that the lack of compliance was justifiable given the size of the company, the complexity of its structure, its history and ownership (Financial Reporting Council, 2018). A similar approach is enshrined within the Australian Code, which is referred to as the 'if not, why not' rule (ASX Corporate Governance Council, 2019). The rule proposes that non-complying companies should provide a "reasonably detailed and informative" explanation of the reasons for their lack of compliance, "so that the market understands why it is that the entity has chosen not to follow that recommendation" (ASX Corporate Governance Council, 2019). This high level of flexibility in both cases emphasises the non-legal nature of CGCs. Governance codes are typically considered as non-binding guidance, which rank in importance after the so called 'hard' law, including statutes and case law, and 'soft' law, such as the listing rules of stock exchanges. In Australia the Corporate Governance Principles and Recommendations are complimentary to the Corporations Act 2001 and the listing rules of the Australian Securities Exchange Limited, whereas The UK Corporate Governance Code accompanies the Companies Act 2006 and the listing rules of the London Stock Exchange. Both in the UK and in Australia the codes apply to listed companies, with private companies being exempt from compliance (ASX Corporate Governance Council, 2019; Financial Reporting Council, 2018). Despite the non-binding status of the codes, at least in Australia the courts have in the past taken into account the principles set out in the country's Code while determining the scope of directors' duties, as illustrated by the decision in Australian Securities and Investments Commission v Rich [2009] NSWSC 1229. Moreover, in both countries the companies are required to include their reports of compliance with the codes' principles in their annual statements (ASX Corporate Governance Council, 2019; Financial Reporting Council, 2018), although the Australian Code further encourages the companies to "streamline their annual report by choosing to publish their governance disclosures (...) on their website" (ASX Corporate Governance Council, 2019). As such, despite their non-binding nature CGCs perform an important role in the corporate governance framework in both countries, in that they constitute a reference point which enables investors to easily verify the compliance of the board of directors in a particular company with their duties as well as to compare and contrast the management structure and effectiveness of different listed companies (Farrar, 2005). However, depending on the principles embedded in the code, compliance might increase the transparency of the board to an extent which makes it uncomfortable or even impossible for the board to take risky decisions that are at times required in order for the company to achieve innovation (Farrar, 2005). A code which encourages an unhealthy level of transparency might hinder the competitive advantage of a company which would otherwise be capable of generating profits for the investors, whereas the lack of compliance with such a code might discourage the investors from investing. As such, the formulation of an effective corporate governance code of conduct is a difficult task which requires the balancing of two opposing interests.

\section{The UK's Corporate Governance Code}

The UK's Code contains a set of principles and provisions which are divided into five sections, focusing on board leadership and company purpose, division of responsibilities between board members, composition, succession and evaluation, audit, risk and internal control as well as remuneration of directors. The vast majority of the provisions within the Code do not impose a significant reporting burden on listed companies, neither do they invite an unduly level of transparency which could inhibit entrepreneurship and innovation. Principles $A$ to $E$ and provisions 1 to 8 which relate to board leadership and company purpose emphasise the need for the board to support the long-term sustainable success of the company (Financial Reporting Council, 2018, Principle E) and encourage the chair of the board to "seek regular engagement with major shareholders in order to understand their views on governance and performance against the strategy" (Financial Reporting Council, 2018, Provision 
3). Principle A directly emphasises that "a successful company is led by an effective and entrepreneurial board" (Financial Reporting Council, 2018), which encourages the innovative drive of board members of listed companies. However, such a drive might be curbed by the strongly prescriptive nature of provision 4 which provides that "when 20 per cent or more of votes have been cast against the board recommendation for a resolution, the company should (...) consult shareholders in order to understand the reasons behind the result" (Financial Reporting Council, 2018). The requirement to conduct such a consultation over a disagreement threshold of only $20 \%$ of shareholders could significantly slow down the decision-making process of the board and negatively affect the board's ability to respond quickly to changing circumstances, e.g. in the context of mergers, acquisitions or new market entrances.

Principles $\mathrm{F}$ to I and provisions 9 to 16 are devoted to the division of responsibility within the board. In particular, principle $\mathrm{F}$ provides that the chair of the board should "demonstrate objective judgement throughout their tenure and promote a culture of openness and debate" (Financial Reporting Council, 2018), whereas provision 11 specifies that at least half of the board should consist of independent non-executive directors (Financial Reporting Council, 2018). The reporting requirements imposed on listed companies with regards to those and other principles and provisions in the same category are reasonable. The companies are required to share with the public a significant amount of detail about the employment history, business relationships, remunerations etc. of their non-executive directors (Financial Reporting Council, 2018, Provision 10) as well as the responsibilities of the chair, the chief executive, any senior independent directors, the board and any committees (Financial Reporting Council, 2018, Provision 14). However, the requirement to disclose such information does not in any manner affect the boards' ability to make swift decisions that will enable the company to innovate and grow. The third category within the Code includes principles $K$ to $L$ and provisions 17 to 23 which relate to the composition, succession and evaluation of the board. Many of the requirements embedded in those principles and provisions directly support entrepreneurship and innovation in listed companies. For instance, provision 19 prohibits the chair of the board from holding their position for longer than 9 years from the date of their first appointment to the board, whereas according to provision 18 the positions of all directors are subject to annual re-election (Financial Reporting Council, 2018). This ensures that the leadership of the company is continuously under the pressure to deliver successful results and boost the company's profits, which increases their drive for innovation and entrepreneurship.

Principles $\mathrm{M}$ to $\mathrm{O}$ and provisions 24 to 31 in the fourth category relate to auditing as well as managing risk and internal control. Provision 24 requires that listed companies establish an audit committee with responsibilities specified in provision 25, which include monitoring the financial statements of the company, providing advice on whether annual reports are fair and balanced, reviewing the company's internal financial controls and risk management systems etc. (Financial Reporting Council, 2018). Moreover, provisions 29 to 31 impose on listed companies extensive reporting requirements with regards to publishing annual risk assessments (Financial Reporting Council, 2018, Provision 29), the expectations with regards to its future operation (Financial Reporting Council, 2018, Provision 31) as well as its financial statements (annually and half-yearly) (Financial Reporting Council, 2018, Provision 30). Such disclosure requirements might be burdensome, but they provide investors and potential investors with valuable information, while at the same time avoiding any interference with the decision-making of the board. As such, they do not in any manner affect the entrepreneurship and innovation within the company. One could further argue that the requirement embedded in provision 31 that the board "should state whether it has a reasonable expectation that the company will be able to continue in operation and meet its liabilities as they fall due over the period of their assessment, drawing attention to any qualifications or assumptions" forces the board to continuously strive to ensure that the company stays relevant and maintains its market position (Financial Reporting Council, 2018).

The final set of requirements imposed on listed companies in principles $P$ to $R$ and provisions 32 to 41 relates to the remuneration of the board members. The requirements in the fifth category are formulated in a manner which ensures that board members are consistently encouraged to pursue innovation with the prospect of increased company profits. For example, provision 37 provides that "remuneration schemes and policies should enable the use of discretion to override formulaic outcomes" (Financial Reporting Council, 2018), which ensures 
that the company maintains its flexibility to reward entrepreneurial efforts that often do not fit well within standard sets of criteria for remuneration assessment. In addition, provision 36 encourages the use of remuneration schemes which "promote long-term shareholdings by executive directors that support alignment with long-term shareholder interests" (Financial Reporting Council, 2018). This important requirement provides the incentive for executive directors to ensure that any decisions made in pursuance of innovation and entrepreneurship by the company serve long-term interests of the shareholders, instead of focusing purely on short-term profits. As such, majority of the principles and provisions within the UK's Code allow board members the freedom to pursue innovation, although the requirement to consult shareholders in case where $20 \%$ or more of them disagree with the board's recommendation embedded in provision 4 could potentially slow down the board's ability to react to the market and make fast decisions in pursuit of innovation.

\section{Australian Corporate Governance Principles and Recommendations}

Contrary to the UK's Code the Australian Code consists of only 8 principles, which are accompanied by recommendations and commentaries. The first principle encourages listed companies to lay solid foundations for management and oversight, in particular by disclosing a charter that sets out the roles and responsibilities of the board as well as any matters reserved to the board or delegated to the management (ASX Corporate Governance Council, 2019, Recommendation 1.1). Recommendations 1.2 to 1.4 regulate the board's relationships with each individual board member as well as the company secretary (ASX Corporate Governance Council, 2019). Those recommendations do not place a significant burden of disclosure on the company, neither do they hinder the board's decision-making power or ability to react quickly to the changing market. In addition, recommendation 1.6 imposes on companies the requirement to establish and disclose to the public "a process for periodically evaluating the performance of the board, its committees and individual directors" (ASX Corporate Governance Council, 2019). As in the case of the UK Code, the commentary to recommendation 1.6 states that such reviews should preferably be conducted annually (ASX Corporate Governance Council, 2019). However, the use of the word 'preferably' as well as the lack a clear indication within the wording of the recommendation itself of the frequency with which performance reviews of board members should be conducted might encourage companies to conduct such reviews less frequently, e.g. every two or three years.

As discussed in the previous section of this article, such reviews have the potential to significantly encourage board members to work towards increasing the company's profits through innovative solutions and decisions. As such, the lack of a clear requirement that the reviews be performed on an annual basis rather than less frequently is disappointing in the context of encouraging the board to promote entrepreneurship within the company. The second principle in the Australian Code seeks to ensure that boards are structured in a manner which makes them effective and adds value to the company, for instance by having a nomination committee (ASX Corporate Governance Council, 2019, Recommendation 2.1) or disclosing the skills matrix of the board (i.e. the "mix of skills that the board currently has or is looking to achieve in its membership") (ASX Corporate Governance Council, 2019, Recommendation 2.1) along with the names of directors and their length of service (ASX Corporate Governance Council, 2019, Recommendation 2.3) etc.

The requirements embedded in this principle relate to the structure of the board rather than its decision-making powers. As such, they do not seem to affect the ability of the board members to lead the company in an innovative direction. Similar conclusions could be made with regards to principle 3, which seeks to "instil a culture of acting lawfully, ethically and responsibly" in listed companies (ASX Corporate Governance Council, 2019, Recommendations 3.1-3.4) and principle 4, which relates to the auditing requirements of the companies with regards to their corporate reports (ASX Corporate Governance Council, 2019, Recommendations 4.1-4.3).

On the other hand, principle 5 places a significant burden of 'timely and balanced' disclosure on listed companies which could potentially affect the board's ability to make quick and effective decisions and lead the company in an innovative direction. The level of disclosure expected of listed companies in Australia is reasonably high. Principle 5 provides that "a listed entity should make timely and balanced disclosure of all matters concerning it that a reasonable person would expect to have a material effect on the price or value of its securities" (ASX 
Corporate Governance Council, 2019). The requirement to make public any information pertaining to the price or value of the company's securities could potentially relate to a wide range of information, including confidential company information the disclosure of which could place the company at a disadvantage when competing in the market. However, such an unduly burden is mitigated by the qualifications of a "reasonable person" and "material effect" which significantly narrow down the disclosure requirements. Nevertheless, recommendations 5.1 to 5.3 made with regards to principle 5 (ASX Corporate Governance Council, 2019) make it difficult to assess exactly what level of disclosure is required of listed companies, which in turn decreases the accountability of board members. Coupled with the lack of a clear review requirement of annual performance reviews with regards to board members, as discussed earlier, this relaxed approach of the Australian Code could be discouraging board members from pursuing innovation and directing the company towards increasing its profits.

Principle 6 of the Australian Code seeks to ensure that the rights of security holders are preserved and that they are provided with "appropriate information and facilities to allow them to exercise their rights as security holders effectively" (ASX Corporate Governance Council, 2019). However, the requirements imposed on listed companies in Australia with regards to the board's communications with security holders are far less prescriptive than those in the UK. For instance, recommendation 6.1 requires that listed companies should provide information about themselves and their governance to investors via their website (ASX Corporate Governance Council, 2019), whereas recommendation 6.2 provides that they should provide investor relations programs to facilitate a two way communication with investors (ASX Corporate Governance Council, 2019). Nevertheless, no indication is made in the recommendations about the type or amount of information to be made available to investors.

Principle 7 of the Australian Code imposes on Australian listed companies a requirement to recognise and manage risk by creating a special risk management committee with at least three members (majority of whom are independent directors) and a chair (who is an independent director) (ASX Corporate Governance Council, 2019, Recommendation 7.1). The presence of such a committee demands that all decisions of the board related to risk-taking, such as investing in new ventures or entering new markets, are subjected to external scrutiny of the committee. The committee not only oversees the company's risk management, but also makes recommendations about any changes that should be made to its risk management framework (ASX Corporate Governance Council, 2019, Commentary).

The committee's role is to verify whether the company is "operating within the risk appetite set by the board" (ASX Corporate Governance Council, 2019, Commentary). This explanation could create an illusion that the committee is ultimately created to assist the company in fulfilling its vision, even where such a vision is highly innovative and entrepreneurial, which carries a significant level of inherent level risk. However, the Code advises that the committee should also "make recommendations to the board in relation to changes that should be made to the entity's (...) risk appetite set by the board" (ASX Corporate Governance Council, 2019, Commentary). In that sense, the committee could constitute a hindrance to the entrepreneurial efforts of a company, particularly one which would otherwise thrive on a risk management plan involving a high level of risk.

Finally, principle 8 of the Australian Code focuses on remuneration, proposing that listed companies should have the level of remuneration which would be sufficient to "align their interests with (...) the entity's values and risk appetite" (ASX Corporate Governance Council, 2019). In addition, the commentary explains further that directors and senior executives should be remunerated in a way which does not reward conduct that is "contrary to the entity's values or risk appetite" (ASX Corporate Governance Council, 2019).

Therefore, the requirements with regards to remuneration do not inhibit rewarding the board and senior executives for pursuing innovation, provided that the level of risk involved is foreseen by the company's strategy. As in case of the UK Code, the Australian Code includes a set of well-formulated principles which - to a large extent - encourage entrepreneurial efforts of the board of directors. However, lessons and 'best practices' could be learned from both Codes. Such best practices will be discussed in the form of recommendations in the following section of this article. 


\section{Recommendations of Best Practices}

The pursuit of entrepreneurship and innovation by companies is a delicate matter which, when done properly, can render a significant yield on investment for the company's shareholders. However, the share value a company which accepts an excessive level of risk might be overly volatile to constitute a sound investment. Equally, taking on a significant amount of risk might lead to substantial losses in the value of the company's shares, to the detriment of the shareholders (Esser et al., 2018). The role of a well-formulated corporate governance code is to impose on listed companies requirements which provide the board of directors with enough freedom to pursue innovation, but which also impose on the board carefully crafted constraints that prevent excessive risk-taking (Morris, 2018). For example, the practice of inserting into the code a clear emphasis on the entrepreneurial efforts of the board, as in principle A of the UK Code, sets the right tone of the code and the expectations with regards to it (Financial Reporting Council, 2018). Such a practice makes it clear that companies should not be afraid of risk-taking and pursuing innovation through their decision-making regardless of their listed status and their responsibilities to the shareholders (Gosling et al., 2018).

Secondly, listed companies should be encouraged to agree on their level of risk-taking as part of the overall company strategy, as encouraged by principle 7 of the Australian Code (ASX Corporate Governance Council, 2019). Such a level should be agreed by the company's board of directors, although feedback from the shareholders should be considered in the process (Palmer, 2017). The incorporation of such feedback at the strategy-setting stage is more effective at enabling the board to make prompt entrepreneurial decisions compared to involving the shareholders directly in the passing of all resolutions, as proposed by the requirement in the UK Code to investigate disagreements of $20 \%$ or more of the shareholders with the board's resolutions (Financial Reporting Council, 2018). The creation of a risk-management monitoring committee which follows the company's risk-taking strategy, as proposed in the Australian Code (ASX Corporate Governance Council, 2019, Recommendation 7.1), is another effective practice which ensures the appropriate balance between risktaking and risk-prevention with regards to board decisions. The establishment of such a committee protects the interests of the shareholders on their behalf, while preventing the slowing down of the board's decisions by imposing the requirement of shareholder consultation (Bailey, 2018).

In addition, the inclusion of independent directors as a significant proportion of the committee, as proposed by the Australian Code (ASX Corporate Governance Council, 2019, Recommendation 7.1), guarantees that the committee members can understand the impact of the board's decisions and assess their risk level while at the same time remaining impartial. Unlike individual shareholders, independent directors have the right expertise and know-how related to the running of a listed company, which at least in some cases makes them more capable of protecting the shareholders' interests compared to the direct involvement of the shareholders in the process (Stretch, 2017).

Moreover, remuneration schemes should encourage the entrepreneurial spirit amongst directors by rewarding them where their risk-taking translates into increased company profits and share value (Stretch, 2017). The inclusion of adaptable remuneration schemes where 'formulaic outcomes' can be overridden through individual discretion - as proposed by the UK Code (Financial Reporting Council, 2018) - ensures a sufficient level of flexibility to enable this. In addition, as proposed by the Australian Code (ASX Corporate Governance Council, 2019), it is good practice for listed companies to ensure that the remuneration of the directors is aligned with the company's strategy, including its acceptable level of risk-taking, so as not to encourage excessively risky decisions which are not in line with the company's vision (Bailey, 2018).

While remuneration could be seen as the main driver behind the board's entrepreneurial efforts, the rules imposed on listed companies with regards to succession and appointment to the board are equally important (Quo, 2018). The requirement that the positions of all directors are subject to annual re-election, incorporated into the UK Code, ensures that board members must continuously strive to increase the company's profits through innovation and entrepreneurship in order to satisfy the shareholders (Financial Reporting Council, 2018). However, it also prevents directors from taking decisions which are overly risky out of the fear of losing 
their position, should the investment fail to pay off (Gosling et al., 2018). Such a requirement would operate particularly well within a company which has a clear risk-taking strategy, as proposed by the Australian Code (ASX Corporate Governance Council, 2019, Recommendation 7.1), given that such a strategy constitutes the framework for assessing whether the decisions of a particular director are excessively risky (Al-Tawil and Younies, 2019). The prohibition imposed on the chair of the board of holding their position for longer than 9 years from the date of their first appointment imposed by the UK Code (Financial Reporting Council, 2018) complements such a framework by ensuring that the main driving force behind the vision of the board remains relevant and adapts to the market conditions and current industry practices (Gosling et al., 2018).

Finally, communication with shareholders and disclosure of information to the public are crucial elements of the management of a listed company which, if not conducted with sufficient care, could inhibit entrepreneurial efforts of the board (Al-Tawil and Younies, 2019). Taking risky decisions is often connected with temporary setbacks which, if disclosed to the shareholders, could negatively affect the share price of the company due to the shareholders' lack of understanding of the company's long-term strategy. As such, it is crucial that listed companies are required to disclose only information which has "material effect" on the company's share price and value or which would be expected to be published by a "reasonable person", as proposed in the Australian Code (ASX Corporate Governance Council, 2019).

However, a well-formulated corporate governance code should also make it clear what specific information should be disclosed by the company, as specified in the UK Code (Financial Reporting Council, 2018, Provision 29), rather than leaving this decision to the boards of individual companies. Clarity with regards to the information that should be disclosed makes it difficult for the boards to decrease their accountability by avoiding the publication of uncomfortable information related to the company's risk-taking and risk management.

The principles-based approach is a strong and crucial element of both codes, which makes it difficult for companies to engage in box-ticking, i.e. checking off the relevant requirements of the code without properly thinking through their incorporation into the company's operation (Reddy, 2019). The "comply or explain" approach in the UK (Financial Reporting Council, 2018) and the "if not, why not" rule in Australia (ASX Corporate Governance Council, 2019) ensure that listed companies take a more responsible stance towards corporate governance. Nevertheless, a corporate governance code should not be the only well-formulated element of the corporate governance framework in any country (Adams, 2017).

Over-reliance on such a code can enable the company to present in its reports the image of a prosperous business while hiding its less acceptable or even illegal practices, which is what happened in the case of Carillion plc, the largest ever listed company to have gone into liquidation in the UK in January 2018 (Companies House, 2018). Carillion's liquidation demonstrates that the board's entrepreneurial efforts may have a negative impact on the share value of the company and even, on occasion, lead to the company's collapse. As such, a dditional measures in the form of effective legislation and the accompanying case law should be established and regularly monitored in any jurisdiction seeking to have an effective corporate governance framework which encourages risk-taking and innovation-seeking amongst the board members while protecting the interests of the shareholders (Adams, 2017).

\section{Conclusion}

As explained above, the CGCs in both Australia and the UK propose advanced approaches to corporate governance which to a significant extent protect the interests of the shareholders while encouraging board members to pursue innovation and entrepreneurship in a safe manner, through the adoption of appropriate risk management measures. Lessons on how to ensure the right balance in this respect can be learned from both codes. In particular, the Australian Code can be praised for imposing on listed companies the requirement to incorporate an agreed level of risk-taking into the company's strategy as well as monitor the board's decisions with regards to risk management. 
The obligation to introduce a risk management committee composed of independent directors and ensure that the remuneration of the directors is aligned with the company's risk management strategy constitute additional layers of both encouragement of innovation and protection from excessive risk-taking. On the other hand, the UK Code can be commended for providing clear emphasis on the entrepreneurial efforts of the board, the inclusion of adaptable remuneration schemes and the requirement that the positions of all directors are subject to annual re-election. A combination of those best practices embedded in the codes of both countries would even further strengthen their corporate governance frameworks with regards to balancing entrepreneurship with excessive risk-taking.

\section{References}

1. Adams, M. (2017). Board diversity and corporate governance: lessons from Australia, India and Asia. Coventry Law Journal, 22(1), pp.1-8.

2. Al-Tawil, T. and Younies, H. (2019). Corporate governance and social responsibility: a comparative analysis of the UK, UAE, Australia and the US. International Company and Commercial Law Review, 30(2), pp.83-102.

3. ASX Corporate Governance Council (2019). Corporate Governance Principles and Recommendations. [online] Available at: https://www.asx.com.au/documents/regulation/cgc-principles-and-recommendations-fourthedn.pdf [Accessed 3 Mar. 2020].

4. Bailey, P. (2018). Financial Reporting Council consults on proposed "shorter and sharper" UK Corporate Governance Code.

5. Bebchuk, L., Cohen, A. and Ferrell, A. (2009). What Matters in Corporate Governance? The Review of Financial Studies, 22(2), pp.783-827.

6. Companies House. (2018). Carillion PLC (03782379). Commencement of winding up: 15 January 2018.

7. Du Plessis, J., Hargovan, A., Harris, J. and Bath, V. (2018). Principles of Contemporary Corporate Governance. Cambridge University Press.

8. Esser, I., MacNeil, I. and Chalaczkiewicz-Ladna, K. (2018). Proposed revisions to the UK Corporate Governance Code: a step forward in recognising a company's responsibilities towards wider stakeholders? Company Lawyer, 39(8), pp.254-256.

9. Farrar, J. (2005). Corporate governance: theories, principles, and practice. Oxford University Press.

10. Financial Reporting Council (2018). THE UK CORPORATE GOVERNANCE CODE. [online] Available at: https://www.frc.org.uk/getattachment/88bd8c45-50ea-4841-95b0-d2f4f48069a2/2018-UK-CorporateGovernance-Code-FINAL.PDF [Accessed 3 Mar. 2020].

11. Fleming, G. (2003). Corporate Governance in Australia. Agenda, 10(3), pp.195-212.

12. Gosling, T., Peaker, M. and Crawford, R. (2018). Corporate governance update: focus on fairness. Compliance \& Risk, 7(3), pp.11-14.

13. Licht, A., Goldschmidt, C. and Schwartz, S. (2005). Culture, Law, and Corporate Governance. International Review of Law and Economics, 25(2), pp.229-255.

14. Morris, G. (2018). Corporate governance changes ahead. Company Secretary's Review, 41(9), pp.136-138.

15. Palmer, J. (2017). Major changes to UK corporate governance ahead. Lloyd's List Insurance Day, Dec(14), p.6. 
16. Quo, S. (2018). Executive remuneration as a mechanism for corporate governance in Australia. Company Lawyer, 39(11), pp.368-377.

17. Ramirez, S. (2007). The End of Corporate Governance Law: Optimizing Regulatory Structures for a Race to the Top. Yale Journal on Regulation, 24(2), pp.313-360.

18. Reddy, B. (2019). Thinking outside the box - eliminating the perniciousness of box-ticking in the new corporate governance code. Modern Law Review, 82(4), pp. 692-726.

19. Stretch, N. (2017). Proposals for reform of corporate governance: executive remuneration aspects. Compliance \& Risk, 6(5), pp.2-4.

20. The Committee on the Financial Aspects of Corporate Governance (1992). The Financial Aspects of Corporate Governance. London.

21. Yeoh, P. (2019). Corporate governance codes in the UK: the risk of over-reliance? Business Law Review, 40(1), pp.19-27. 